\title{
UDC 621.039.53
}

O.V. Korolyov ${ }^{1}$, DEng, Prof., O.P. Ishchenko ${ }^{2}$

${ }^{1}$ Odessa National Polytechnic University, 1 Shevchenko Ave., 65044 Odessa, Ukraine; e-mail: korolyov118@gmail.com

${ }^{2}$ SD "South-Ukraine NPP”, 55000 Yuzhnoukrainsk, Ukraine

\section{INVESTIGATION OF THE INFLUENCE OF VARIOUS FACTORS ON THE POWER OF HEAT EXCHANGE BY RADIATION}

О.В. Корольов, О.П. Іщенко. Вплив геометричних параметрів на теплообмін в тісній решітці активної зони реактора. Питання щодо недостатньої вивченості процесів теплообміну випромінюванням неодноразово поставало в різних дослідженнях. Незважаючи на те, що роботи з вивчення теплообміну випромінюванням охоплюють широкий спектр різних галузей, слід зазначити недостатню кількість матеріалів з дослідження процесів теплообміну випромінюванням в активній зоні ядерного реактора. У роботі об'єктом дослідження є тепловиділяючі збірки реактора ВВЕР-1000. Мета: Метою роботи є дослідження процесу теплообміну випромінюванням між тепловиділяючими збірками, а також дослідження впливу зміни відстані між тепловиділяючими збірками на їх потужність з урахуванням взаємного підсвічування збірок. Матеріали і методи: Наведено загальний опис процесу теплообміну випромінюванням. Проведено розрахункове дослідження впливу геометричних параметрів на теплообмін в тісній решітці активної зони реактора. Досліджено вплив теплообміну випромінюванням на зміну температури поверхні тепловиділяючих збірок реактора ВВЕР-1000 при зміні міжкасетного зазору. Досліджено зміну потужності тепловиділяючих збірок відносно початкової потужності при зміні міжкасетного зазору. Проведено експериментальні вимірювання температури на різній відстані від джерела випромінювання при наявності перешкоди на шляху поширення випромінювання у вигляді скла і води різного рівня. Виконано розрахунок потужності теплового випромінювання та конвективного теплообміну на підставі отриманих даних експерименту. Результати: Результати розрахунку свідчать, що в моделях, які визначають розрахунковим шляхом температуру тепловиділяючих збірок в активній зоні реактора ВВЕР-1000, необхідно враховувати теплообмін випромінюванням. За результатами експерименту визначено, що наявність води практично не впливає на потужність теплообміну випромінюванням. Це дозволяє не враховувати наявність води при розрахунку теплообміну випромінюванням між тепловиділяючими збірками в реакторі BВEР-1000.

Ключові слова: теплообмін випромінюванням, ВВЕР-1000, тепловиділяюча збірка, тісна решітка, геометричні параметри.

O.V. Korolyov, O.P. Ishchenko. Investigation of the influence of various factors on the power of heat exchange by radiation. The issue of lack of knowledge of radiation heat transfer process has been repeatedly raised in various studies. Despite the fact that works on study of heat transfer by radiation covers a wide range of different industries, it should be noted the lack of materials on study of heat exchange processes by radiation in a core of a nuclear reactor. In this work, the fuel assemblies of the VVER-1000 reactor were used as the bodies under study. Aim: The aim of the research is to investigate the heat exchange process between heat transfer assemblies and to study of the effect of changing the distance between the fuel assemblies on their power taking into account the inter-radiating of assemblies. Materials and Methods: A general description of the process of heat transfer by radiation. A calculation study of the effect of geometric parameters on heat transfer in the close lattice of the reactor core is performed. The influence of heat transfer by radiation on the temperature change of the fuel assemblies surface of the VVER-1000 reactor at change in the cassette gap is studied. The change in the power of the fuel assemblies relative to the initial power with a change in the cassette gap was studied. Experimental measurements of the temperature at different distances from the radiation source were made with an obstacle in the path of radiation propagation in the form of glass and water of different levels. The heat radiation and convective heat transfer are calculated based on the obtained experimental data. The calculation of thermal radiation power and convective heat transfer based on the obtained experimental data is performed. Results: The calculation results show that in models that determine the temperature of the fuel assemblies in the core of the VVER-1000 reactor, the radiation heat transfer must be taken into account. In this case, the amount of transferred energy is the greater, the smaller the distance between objects. This is observed depending on the distance between the fuel assemblies and their power. According to the results of the experiment, it is determined that the presence of water practically does not affect the power of heat exchange by radiation. This makes it possible not to take into account the presence of water in calculating the heat exchange between the fuel assemblies in the VVER-1000 reactor.

Keywords: heat transfer by radiation, VVER-1000, fuel assembly, close lattice, geometric parameters.

Introduction. All substances continuously emit electromagnetic waves due to vibrations of their atoms and molecules. These oscillations are directly related to the internal energy of matter. In an equilibrium state, the internal energy is proportional to the temperature of the substance.

Radiation heat exchange is taken into account in studies on cooling processes, for example, in the study of heat transfer in a movable metal sheet with jet cooling [1]. 
The problem of the insufficient study of the processes of heat exchange by radiation was repeatedly raised in various studies, for example, in a paper devoted to the peculiarities of heat exchange in the cylinder of diesel engines in gas-engine fuel [2], as well as in the investigation of processes in the tuyere zone of a blast furnace when working with Using pulverized coal [3], etc.

Despite the fact that the work on the study of heat transfer by radiation covers a wide range of different industries, it should be noted the lack of materials on the study of heat exchange processes by radiation in the core of a nuclear reactor. So, in this work, the fuel assemblies (FA) of the VVER-1000 reactor were used as the bodies under study.

The aim of the research is to investigate the heat exchange process between heat transfer assemblies and to study of the effect of changing the distance between the fuel assemblies on their power taking into account the inter-radiating of assemblies.

We note that the question of impact of accounting of the assemblies radiance by each other [4] in the literature at the moment was considered only from the point of view of the change in the curvature of the FA [5].

Analysis of the literature showed a lack of data in the study of heat transfer by radiation, as well as the lack of valid data on the degree of absorption of radiant energy in the water layer. To confirm these calculations, the present experimental investigation has been carried out.

The aim of the experiment is the determination of dependence of the radiation power on the distance to the radiation source without barriers and the effect of the presence of a barrier in the form of a different layer of water.

Materials and Methods.

Radiation heat transfer. The maximum temperature difference between fuel assemblies located side by side in the core of the VVER-1000 reactor, according to the temperature sensors at the outlet from the fuel assembly, is $11.5^{\circ} \mathrm{C}$ (data of Nov. 09, 2014 on the South-Ukraine NPP, unit No. 3, 290 effective days).

The formula was used for absolutely black body in the calculation of the resulting radiation, which made it possible to determine the maximum possible value of the transmitted energy.

To calculate the heat transfer by radiation, we use the formula [6]

$$
Q_{1 \leftrightarrow 2}=\sigma\left(T_{1}^{4}-T_{2}^{4}\right) A F_{1 \leftrightarrow 2},
$$

where $\sigma-$ Stefan-Boltzmann constant (takes into account radiation over all wavelengths);

$T_{1}$ - source temperature, $\mathrm{K}$;

$T_{2}$ - thermocouple temperature, $\mathrm{K}$;

$A$ - heat exchange area, $\mathrm{m}^{2}$;

$F_{1 \leftrightarrow 2}$ - slope coefficient.

The calculation for fuel rods, presented in the form of parallel rectangles arranged side by side, is described below. The angular coefficient is determined by the formula:

$$
\begin{aligned}
F_{1-2}= & \frac{2}{\pi X Y}\left(\ln \left(\frac{\left(1+X^{2}\right)\left(1+Y^{2}\right)}{1+X^{2}+Y^{2}}\right)^{1 / 2}+X \sqrt{\left(1+Y^{2}\right)} \operatorname{arctg}\left(\frac{X}{\sqrt{1+Y^{2}}}\right)+\right. \\
& \left.+Y \sqrt{\left(1+X^{2}\right)} \operatorname{arctg}\left(\frac{Y}{\sqrt{1+X^{2}}}\right)-X \operatorname{arctg} X-Y \operatorname{arctg} Y\right),
\end{aligned}
$$

where $X=a / S$;

$Y=b / S$;

$a$ - height of the fuel column in the fuel assemblies, $a=3530 \mathrm{~mm}$;

$b$ - width of the facet of the hexagon of the fuel assembly, $b=127.5 \mathrm{~mm}$;

$S$ - distance between the fuel assemblies, $\mathrm{mm}$.

The area $A$ of the heat exchange surface is equal to the area of the rectangle accepted in the calculation of the slope coefficient $A=a \times b=0.45 \mathrm{~m}^{2}$. 
The results of the power of heat exchange by radiation for different distances between fuel assembles calculating are summarized in Table 1.

Table 1

The values of the power of heat exchange by radiation for a different distance between fuel assembles (rectangular shape)

\begin{tabular}{c|c|c|c|c|c}
\hline$S, \mathrm{~mm}$ & 5 & 10 & 13 & 16 & 19 \\
\hline$Q_{1 \leftrightarrow 2}, \mathrm{~kW}$ & 14.986 & 14.289 & 13.971 & 13.567 & 13.431 \\
\hline
\end{tabular}

The results of calculations of the radiation heat exchange power, shown in the graph (Fig. 1), shows a tendency to decrease in power as the distance between the fuel assemblies increases.

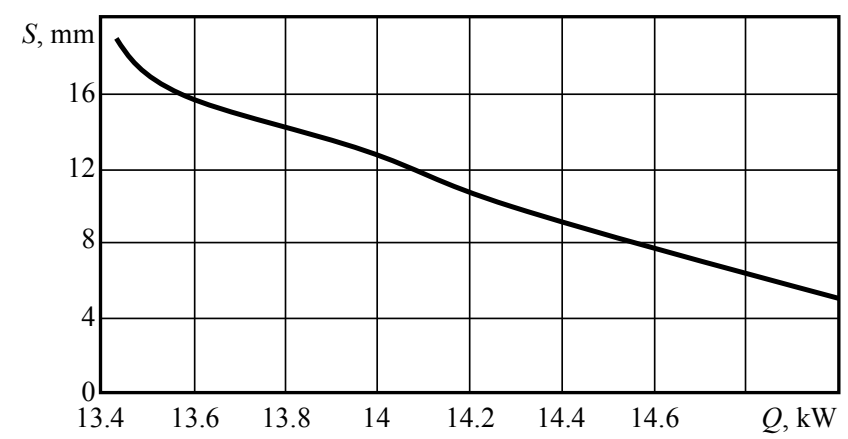

Fig. 1. Dependence of the heat exchange power by radiation on the distance between fuel assemblies, represented as parallel rectangles arranged opposite to each other

The calculation was performed for fuel assemblies represented as parallel cylinders arranged opposite each other. In this case, the slope coefficient is determined by the formula:

$$
F_{1-2}=\frac{1}{\pi}\left(\sqrt{X^{2}-1}+\arcsin \frac{1}{X}-X\right)
$$

where $X=1+S /(2 r)$;

$S$ - distance between the fuel assemblies, mm [7];

$r$ - radius of the cylinder, $r=117 \mathrm{~mm}[8]$.

The area $A_{1}$ of the heat exchange surface is equal to half the surface area of the cylinder adopted in calculating the angular coefficient:

$$
A_{1}=\frac{2 \pi h r}{2}=3.14 \cdot 3.53 \cdot 117 \cdot 10^{-3}=1.29 \mathrm{~m}^{2},
$$

where $h$ - height of the cylinder, is assumed equal to the height of the fuel column in the fuel assembly $(h=3.53 \mathrm{~m})$.

The results of the power of heat exchange by radiation for different distances between fuel assembles calculating are summarized in Table 2.

Table 2

The values of the radiant heat exchange power for different distances between the fuel assemblies (cylindrical shape)

\begin{tabular}{l|c|c|c|c|c}
\hline$S, \mathrm{~mm}$ & 5 & 10 & 13 & 16 & 19 \\
\hline$Q_{1 \leftrightarrow 2}, \mathrm{~kW}$ & 19.5 & 18.4 & 17.9 & 17.5 & 16.8 \\
\hline
\end{tabular}


The results of calculating the power of heat exchange by radiation show a tendency to decrease the power of heat exchange by radiation as the distance between the fuel assemblies of the cylindrical shape increases, located parallel to each other (Fig. 2).

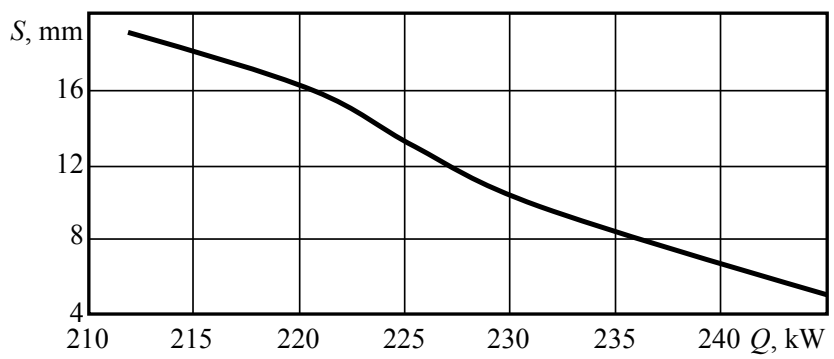

Fig. 2. Dependence of the heat exchange power by radiation on the distance between fuel assemblies, represented as parallel cylinders arranged opposite to each other

Radiation transfers about 13.4...14.9 kW of thermal energy by heat exchange. Depending on how we represent the fuel assemblies - in the form of parallel rectangles or cylinders located opposite each other, the result differs by $3 \ldots .5 \mathrm{~kW}$ in favor of fuel assemblies of cylindrical shape. The transmitted power is higher than for fuel assemblies in the form of rectangles and equal to $16.8 \ldots 19.5 \mathrm{~kW}$. When fuel assemblies is approached, the energy that transferred by heat exchange by radiation, increases.

Experimental stand and methodology. The appearance of the experimental stand is shown in Fig. 3; a schematic sketch of the stand is shown in Fig. 4 and 5.

Two glasses $26 \times 18 \mathrm{~cm}$ with thickness of $8 \mathrm{~mm}$ were used to organize the barrier on the way of the propagation of thermal radiation. Rubber bands were pasted at three sides, thus a free space for water were created. The gap between glasses was $4 \mathrm{~mm}$. A halogen linear lamp J118/R7s with a nominal power of $300 \mathrm{~W}$ was used as a source of radiation. The temperature was measured by the chromel-alumel thermocouple (K-Type) and the Mastech MS 6501 thermometer with a range from 50 to $150^{\circ} \mathrm{C}$ and accuracy of $0.1{ }^{\circ} \mathrm{C}$. The water temperature was measured by a mercury thermometer with a measurement scale from 0 to $50^{\circ} \mathrm{C}$ and a fission rate of $0.1^{\circ} \mathrm{C}$.

Registration of changes in the thermometer readings in time ("acceleration curve") was performed using the Casio EX-FS10 digital camera.

The lamp power was continuously measured with a Lemanso LM602 wattmeter with a range of $0 \ldots 3000 \mathrm{~W}$ and accuracy of $0.1 \mathrm{~W}$. The power of the source measured before the experiment was $287.6 \mathrm{~W}$ (depends on the electric line voltage).

Also, a water tank with the thermocouple placed below it was used during the experiment (Fig. 3). Thus, it is possible to compare the results of heating in the presence of different thicknesses of the water layer.

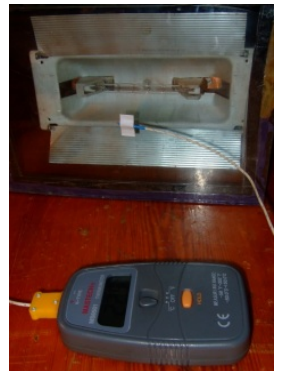

Fig. 3. The visual appearance of the experimental stand

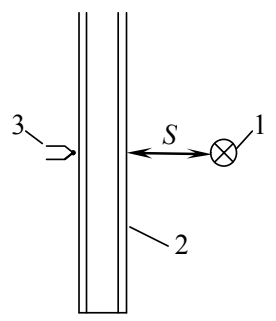

Fig. 4. Sketch of the experimental stand: 1 - radiation source, 2 glasses, 3 - thermocouple

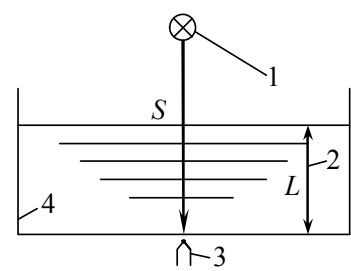

Fig. 5 Sketch of the experimental stand: 1 - radiation source, 2 - water level, 3 - thermocouple, 4 - container 
The experiment was performed according to the following procedure. At a certain distance of one side of glasses is a radiation source, the thermocouple is fixed to the glass without touching the glass. Simultaneously with the lamp the stopwatch is activated and the temperature is recorded until stabilization occurs. Then the space between the glasses is filled with water and a second measurement takes place. After this, the distance from the radiation source changes and another measurement takes place. Then the thermocouple is mounted on a white reflective surface so that the tail of thermocouple end does not come into contact with any surface, the radiation source is installed at a certain distance above the thermocouple. After that, the temperature is measured. Then a glass container with a glass thickness of $1.5 \mathrm{~mm}$ is installed above the thermocouple and the following measurement is made. After that, water is poured into the tank and temperature measurements are made at different water levels, while the temperature of the water in the tank is fixed. A measurement of the cooling rate of the thermocouple in the air was also made.

Results and Discussion. The results of temperature measurements in time are presented in Fig. 6 . Point 0 corresponds to the time when the radiation source is turned off; further on the graphs point 0 corresponds to the time of activation of radiation source.

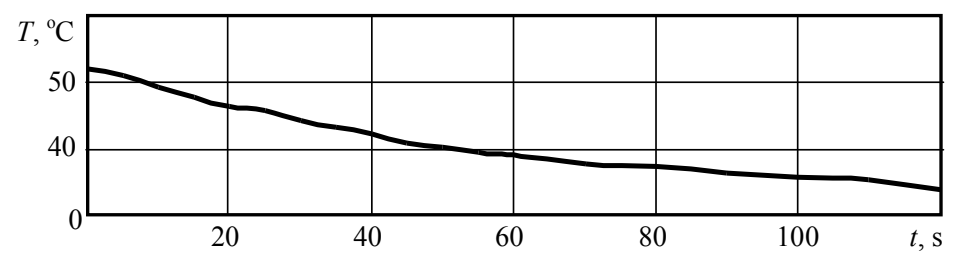

Fig. 6. The graph of the temperature changes over time. Cooling in the air

In the Fig. 7 the effect of the water layer on the thermocouple heating speed is clearly shown, so line 1 , which displays heating without water, increases faster than line 2 , which displays heat in the presence of water layer at the same distance to the source of radiation. The differences in the heating rate, which represent series 2 and 3, show the effect of the distance on heating, so with an increase of distance by $13.4 \%$, the heating rate decreases average in two times. couple.

Fig. 8 shows the influence of the increase in the water layer on the heating speed of the thermo-

Fig. 9 shows the difference between the heating rate of the thermocouple without the presence of a barrier in the path of radiation propagation and in the presence of a glass bulb between the radiation source and the thermocouple, so in the presence of glass with a thickness of $1.5 \mathrm{~mm}$, the heating rate averagely increases by $85 \%$.

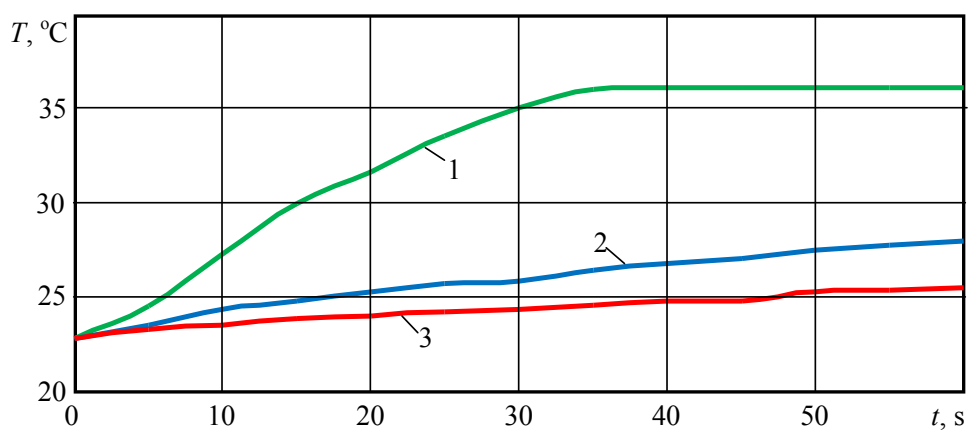

Fig. 7. The temperature graph of the thermocouple in time in the presence of barriers and constant layer of water $(L): 1$ - heat exchange through glass without layer of water, $S=186 \mathrm{~mm}$; 2 - heat exchange through layer of water $L=4 \mathrm{~mm}$ and glass, $S=186 \mathrm{~mm} ; 3$ - heat exchange through layer of water $L=4 \mathrm{~mm}$ and glass, $S=211 \mathrm{~mm}$. 


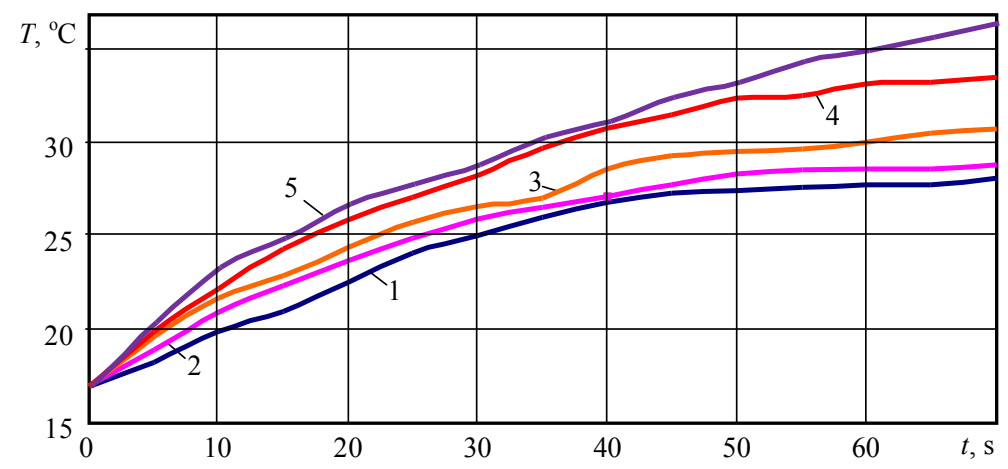

Fig. 8. The graph of the temperature change of the thermocouple in time as the radiation passes through layer of water of various thicknesses $(L)$ at a constant distance "thermocouple-light source" equal to $S=195 \mathrm{~mm}$ : $1-L=20 \mathrm{~mm} ; 2-L=37 \mathrm{~mm} ; 3-L=53 \mathrm{~mm} ; 4-L=70 \mathrm{~mm} ; 5-L=87 \mathrm{~mm}$

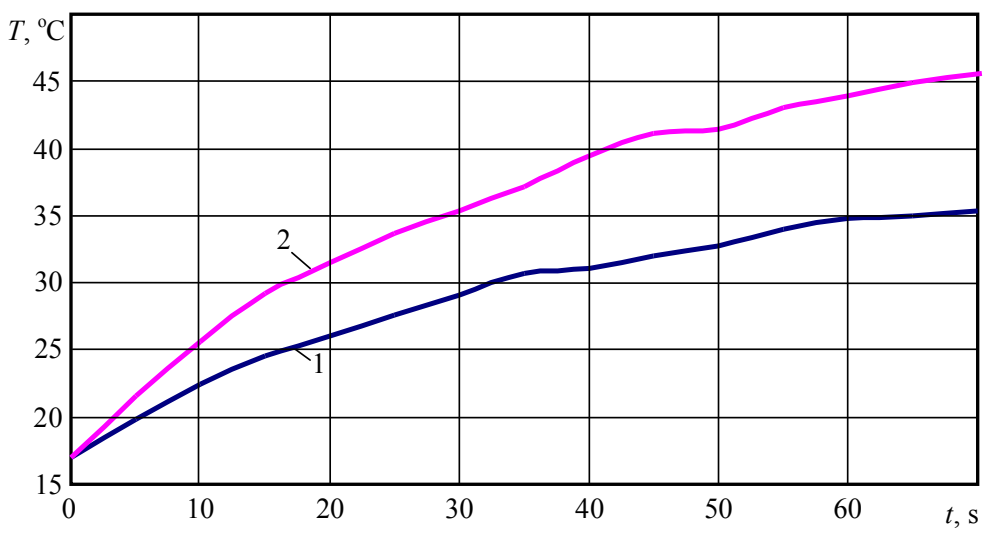

Fig. 9. The graph of the temperature variation of the thermocouple in time: 1 - heat exchange without barriers; $S=195 \mathrm{~mm} ; 2$ - heat exchange through a flask without layer of water $(L=0 \mathrm{~mm}) ; S=195 \mathrm{~mm}$

The calculation of radiation power. To calculate the heat transfer by radiation $Q_{\text {rad, }}$, we use the formula (1). Due to the cylindrical shape of heat source, we use the formula (3) to calculate the slope coefficient $F_{1 \leftrightarrow 2}$; the distance from the source to the thermocouple is $S=186,195,211 \mathrm{~mm}$ for the corresponding experiments.

The values of the slope coefficients are summarized in Table 3.

Table 3

The values of the slope coefficients for different distances to the radiation source

\begin{tabular}{l|c|c|c}
\hline$S, \mathrm{~mm}$ & 186 & 211 & 195 \\
\hline$F_{1-2}$ & 0.1075 & 0.0949 & 0.103 \\
\hline
\end{tabular}

For further calculations of the power of heat exchange by radiation, it is necessary to determine the temperature of the source $T_{1}$. We use the Stefan-Boltzmann law [9]:

$$
T=\sqrt[4]{\frac{W}{\varepsilon A \sigma}}
$$

where $T$ - source temperature, $\mathrm{K}$;

$W$ - radiation power, $\mathrm{W}$;

$\varepsilon$ - degree of blackness for tungsten $(\varepsilon=0.35)[10]$;

$\sigma$ - Stefan-Boltzmann constant;

$A$ - area of the radiating surface, $\mathrm{m}^{2}$. 
Let calculate the area of the cylinder $(A)$ with diameter $1 \mathrm{~mm}$ and height $80 \mathrm{~mm}$ :

$$
A=\pi d h=\pi \cdot 10^{-3} \cdot 8 \cdot 10^{-2}=2.51 \cdot 10^{-4}, \mathrm{~m}^{2},
$$

thus,

$$
T=\sqrt[4]{\frac{287.6}{0.35 \cdot 2.51 \cdot 10^{-4} \cdot 5.67 \cdot 10^{-8}}}=2756.5 \mathrm{~K}
$$

To calculate the convective heat transfer of a thermocouple with the environment we use the formula [6]:

$$
Q_{c}=\alpha A_{1}\left(T_{1}-T_{2}\right), \mathrm{W},
$$

where $\alpha$-heat transfer coefficient, $\mathrm{W} / \mathrm{m}^{2} \mathrm{~K}$;

$A_{1}$ - area of heat exchange, $\mathrm{m}^{2}$;

$T_{1}$ - thermocouple temperature after stabilization during heating, $\mathrm{K}$;

$T_{2}$ - environment temperature, $\mathrm{K}$.

The heat exchange area is equal to the area of the thermocouple's tail end, which has a spherical shape with diameter of $1 \mathrm{~mm}, A_{1}=4 \pi \mathrm{r}^{2}$, where $r$ is the radius of the sphere, $\mathrm{m}$.

$$
A_{1}=4 \pi r^{2}=4 \pi\left(0.5 \cdot 10^{-3}\right)^{2}=3.14 \cdot 10^{-6}, \mathrm{~m}^{2},
$$

Let us assume heat transfer coefficient $\alpha$ for air in the absence of wind equal to $153.7 \mathrm{~W} / \mathrm{m}^{2} \mathrm{~K}$. This value was obtained by measuring the cooling rate of a thin wire in air [11].

The product $\alpha T_{t c}=$ const ( $T_{t c}$ - the time constant of the thermocouple) is valid for all the experiments performed, because the same thermocouple was used.

Let us determine $T_{t c}$ for the experiment with cooling the thermocouple in air along the tangent line to the acceleration curve at the point $t=0$. Thus, the time constant of the thermocouple $T_{t c}$ is $55 \mathrm{sec}$. In the same way we define $T_{t c}$ for the remaining experiments.

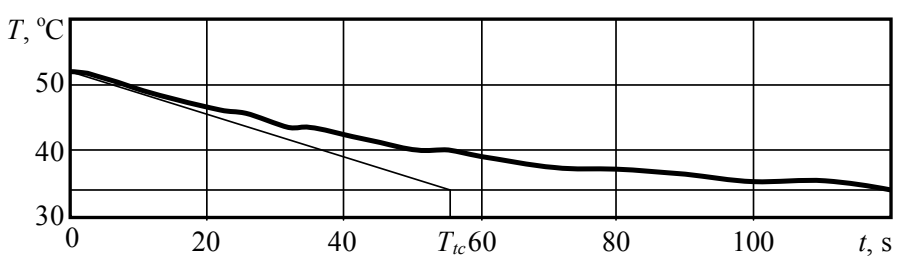

Fig. 10. Determination of $T_{t c}$ for a time-temperature plot for cooling the thermocouple in air

Using the relation $T_{t c_{0}} \alpha_{0}=T_{t c_{i}} \alpha_{i}$ we determine $\alpha_{i}$ for all the experimental measurements, where $T_{t c_{0}} \alpha_{0}$ is used to measure the cooling rate in air, and $T_{t c_{i}} \alpha_{i}$ - for other experimental measurements.

The results of the calculations of the heat transfer coefficient, the radiant heat transfer power, and the convective heat transfer of the thermocouple losses during cooling in air, the measured time constants, as well as the results of measurements of the water temperature in the reservoir during the experiments are summarized in Table 4.

The results of calculations show that the power of heat exchange by radiation does not change in experiments 2 and 3 . In the experiment 1 , the value of the heat exchange power by radiation differs in the third line in comparison with lines 1 and 2 . The power of convective heat transfer when the thermocouple is cooled under the influence of a colder environment is 3...4 orders lower than the power of heat exchange by radiation. The heating of the water during the experiment 2 was near $2 \ldots 3{ }^{\circ} \mathrm{C}$, which indicates a slight loss of the thermal radiation power due to the presence of water on the propagation path during the time of the experimental measurements.

The dependence of the thermal radiation power on the distance was revealed during the experiment: in experiment 1 with an increase in the distance by $25 \mathrm{~mm}$, the power of heat exchange by radiation decreased by $11.7 \%$. In the calculations of the change in the power of heat exchange by radiation, 
the decrease in power with an increase in the distance by $14 \mathrm{~mm}$ was $10.3 \%$ when calculating heat transfer between plates (as in this investigation) and by $13.7 \%$ in the calculation of heat transfer between the cylinders.

Table 4

Summary table of calculation results

\begin{tabular}{c|c|c|c|c|c|c}
\hline Experiment & $T_{t c}, \mathrm{c}$ & $\begin{array}{c}\alpha, \\
\mathrm{W} / \mathrm{m}^{2} \mathrm{~K}\end{array}$ & $Q_{C}, \mathrm{~W}$ & $Q_{\text {rad }}, \mathrm{W}$ & $T_{\text {initial }}{ }^{\circ} \mathrm{C}$ & $T_{\text {final }},{ }^{\circ} \mathrm{C}$ \\
\hline Experiment No.1 & & & & & & \\
Line 1 & 18 & 469.6 & 0.0195 & 15.383 & & \\
Line 2 & 22 & 384.2 & $6.21 \cdot 10^{-3}$ & 15.384 & \multicolumn{2}{l}{} \\
Line 3 & 23 & 367.5 & $2.94 \cdot 10^{-3}$ & 13.58 & & \\
\hline Experiment No.2 & & & & & & \\
Line 1 & 34 & 248.6 & 0.0107 & 42.342 & 13.2 & 17,2 \\
Line 2 & 23 & 367.5 & 0.0166 & 42.342 & 15.3 & 17,9 \\
Line 3 & 24 & 352.2 & 0.019 & 42.342 & 16.6 & 17,5 \\
Line 4 & 30 & 281.7 & 0.0188 & 42.342 & 17.4 & 19 \\
Line 5 & 28 & 301.9 & 0.022 & 42.342 & 18.8 & 19,2 \\
\hline Experiment No.3 & & & & & & \\
Line 1 & 33 & 256.1 & 0.014 & 42.342 & & \\
Line 2 & 28 & 301.8 & 0.023 & 42.342 & & \\
\hline
\end{tabular}

The obtained results show a high convergence of the calculating investigation and the experimental one, which allows us to conclude that the results of the calculation work are reliable.

Conclusions. To determine the maximum possible amount of energy that can be transferred by radiation heat exchange, the fuel assemblies are taken as absolutely black body. The results of the calculation show that in models that numerically determine the temperature of the fuel assemblies in the core of the VVER-1000 reactor, the heat transfer must be taken into account. In this case, the amount of transferred energy is greater, the smaller the distance between objects, which is observed depending on the distance between the fuel assemblies and their power.

A high convergence of the dependence of the radiant heat exchange power on the distance obtained in this work and the calculated one was determined during the experiment.

Based on the results of the processing of experimental measurements, it is determined that the presence of water, as a barrier, does not have a significant effect on the power of heat exchange by radiation. This allows not taking into account the presence of water in calculating the heat exchange between the fuel assemblies in the VVER-1000 reactor.

The magnitude of the convective heat transfer between the thermocouple and the colder ambient air is so small, in comparison with the thermocouple obtained that the value of the heat-exchange capacity of the radiation, that it can be ignored. This makes it possible to consider the calculated heatexchange power of radiation to be reliable.

\section{Література}

1. Колдин, А.В. Исследование теплообмена в подвижном металлическом листе при струйном охлаждении / А.В. Колдин, Н.И. Платонов, В.П. Семенов // Вестник ЧелГУ. - 2008. - № 25(126). C. $60-67$.

2. Лиханов, В.А. Особенности теплообмена излучением в цилиндре дизелей при работе на газомоторном топливе / В.А. Лиханов, А.В. Россохин // Международный журнал прикладных и фундаментальных исследований. - 2014. - № 10, Ч. 1. - С. 14-17.

3. Моторина, Т.А. Исследование теплообмена в фурменной зоне доменной печи при работе с применением угольного топлива (ПУТ) / Т.А. Моторина // Металлургия XXI столетия глазами молодых: всеукраинская научно-практическая конференция студентов: сборник докладов. Донецк: ДонНТУ, 2013. - С. 128-129. 
4. Lebrun, A. Non destructive assay of nuclear LEU spent fuels for burnup credit application / A. Lebrun, G. Bignan // Technical Committee Meeting on Implementation of Burnup Credit in Spent Fuel Management Systems, 10-14 Jul 2000, Vienna, Austria. - Vienna: IAEA, 2001. - PP. 251-268.

5. Afanasyev, A. WWER-1000 fuel cycle economical improvement by reaching high fuel burnup [Електронний ресурс] / A. Afanasyev // International Atomic Energy Agency (IAEA). - Режим доступу: https://inis.iaea.org/search/search.aspx?orig_q=RN:36040495 (Дата звертання: 28.11.2016).

6. Howell, J.R. Thermal radiation heat transfer / J.R. Howell, R. Siegel, M. Pinar Menguc. $-5^{\text {th }}$ Ed. - Boca Raton: CRC Press, 2011. - 987 p.

7. Frost, B.R.T. Nuclear fuel elements: design, fabrication and performance / B.R.T. Frost. - Oxford: Pergamon Press, 1982. - 275 p.

8. Маргулова, Т.Х. Атомные электрические станции / Т.Х. Маргулова. - 4-е изд., перераб. и доп. М.: Высш. шк., 1984. - 303 с.

9. Jevremovic, T. Nuclear principles in engineering / T. Jevremovic. $-2^{\text {nd }}$ Ed. - New York: Springer, 2009. $-546 \mathrm{p}$.

10. Тугоплавкие материалы в машиностроении / под ред.: А.Т. Туманова, К.И. Портного. - М.: Машиностроение, 1967. - 392 с.

11. Королев, А.В. Особенности теплообмена на электрически обогреваемой проволоке в воздухе / А.В. Королев // Пр. Одес. політехн. ун-ту. - 2000. - Вип. 3(12). - С. 80-83.

\section{References}

1. Koldin, A.V., Platonov, N.I., \& Semenov, V.P. (2008). Study on heat transfer of a moving metal strip cooling by jet system. Bulletin of Chelyabinsk State University, 25, 60-67.

2. Likhanov, V.A., \& Rossokhin, A.V. (2014). Peculiar properties of radiative heat transfer in the diesel cylinder operating on gas-engine fuel. International Journal of Applied and Fundamental Research, 10, $14-17$.

3. Motorina, T.A. (2013). Research of heat transfer in a tuyere-raceway of a blast furnace when using coal fuel. In Proceedings of the All-Ukrainian Scientific-Practical Conference of Students "Metallurgy of the $21^{\text {st }}$ Century through the Eyes of Young” (pp. 128-129). Donetsk: DonNTU.

4. Lebrun, A., \& Bignan, G. (2001). Non destructive assay of nuclear LEU spent fuels for burnup credit application. In Proceedings of a Technical Committee Meeting on Implementation of Burnup Credit in Spent Fuel Management Systems (pp. 251-268). Vienna: IAEA.

5. Afanasyev, A. (2003). WWER-1000 fuel cycle economical improvement by reaching high fuel burnup. $I A E A$. Retrieved from https://inis.iaea.org/search/search.aspx?orig_q=RN:36040495

6. Howell, J.R., Siegel, R., \& Pinar Menguc, M. (2011). Thermal Radiation Heat Transfer (5 ${ }^{\text {th }}$ Ed.). Boca Raton: CRC Press.

7. Frost, B.R.T. (1982). Nuclear Fuel Elements: Design, Fabrication and Performance. Oxford: Pergamon Press.

8. Margulova, T.Kh. (1984). Nuclear Power Stations. Moscow: Vysshaya Shkola.

9. Jevremovic, T. (2009). Nuclear Principles in Engineering ( $2^{\text {nd }}$ Ed.). New York: Springer.

10. Tumanov, A.T., \& Portnoy, K.I. (Eds.). (1967). Refractory Materials in Mechanical Engineering. Moscow: Mashinostroenie.

11. Korolyov, A.V. (2000). Heat exchange peculiarities on electric heated wire in air. Odes'kyi Politechnichnyi Universytet. Pratsi, 3, 80-83. 